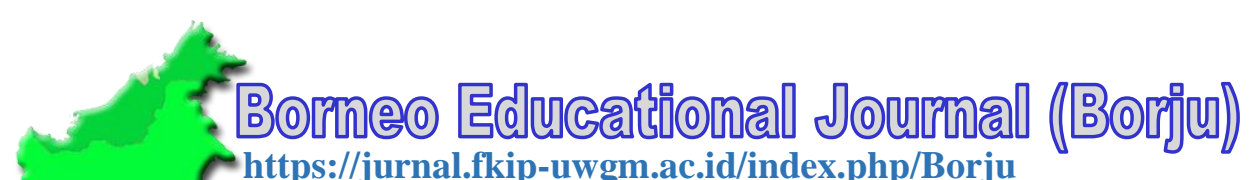

https://jurnal.fkip-uwgm.ac.id/index.php/Borju

E-ISSN: 2655-9323

August 2020, Vol.02 No.02

\title{
The Teachers Exploring Students' Speaking Skill using Hypnoteaching
}

\author{
Rahmaniah $^{1}$, Abdul Rohman ${ }^{2}$ \\ Universitas Widya Gama Mahakam, Indonesia ${ }^{1,2}$ \\ Email Correspondence: rahma.kpn@gmail.com
}

\begin{abstract}
Hypnoteaching could be a "new" strategy or procedure in education, especially in the teaching and learning process. Furthermore, hypnoteaching was an activity in which the teacher gave affirmative or positive words. Hypnosis is usually described or done with a conscious state where. In teaching, hypnosis collaboration with the activity is that the teacher gave a positive word to students. This study was conducted in M.A. Sabillarasyad. To found the result in this study researcher used interviews were as an instrument to collect the data. The subjects in this study are three teachers. The result showed that students' speaking problems were reduced, and the students were more confident after the teacher used hypnoteaching, in which the teachers gave positive words to students by repetition. Furthermore, the students more relax and enjoy the learning process. The researcher found the HT1 as the teacher one used hypnoteaching in order for students focused on there did not aware when the teacher did hypnoteaching. Therefore the students feel more closely with the teacher when their inside or outside the class. The researcher concludes that Hypnoteaching was a suitable method for reducing students' speaking problems and helped the teacher manage the classroom in the learning process.
\end{abstract}

Keywords: Speaking; Hypnosis; Teaching; Hypnoteaching; Exploring.

\begin{tabular}{l|ll}
\hline DOI & $:$ & https://doi.org/10.24903/bej.v2i2.628 \\
\hline Received & $:$ & May 2020 \\
\hline Accepted & $:$ & July 2020 \\
\hline Published & $:$ & August 2020 \\
\hline $\begin{array}{l}\text { Copyright and } \\
\text { License }\end{array}$ & $\begin{array}{l}\text { Authors retain copyright and grant the journal right of first publication with the } \\
\text { work simultaneously licensed under a Creative Commons Attribution 4.0 } \\
\text { International License that allows others to share the work with an acknowledgment of } \\
\text { the work's authorship and initial publication in this journal. }\end{array}$ \\
\hline & CC (i) \\
\hline
\end{tabular}




\section{INTRODUCTION}

Hypnoteaching is a tool or method that could help students increase motivation. Furthermore, hypnoteaching was an activity in which teachers gave affirmative or positive words [1] . Hypnosis is usually described or done with a conscious state where. In teaching, hypnosis collaboration with the activity is the teacher gave a positive word to students) [2]. Therefore, other experts had the same definition or stated with Hypnoteaching is a strategy or method to activate students' learning abilities by giving positive affirmation [3]. On the other hand, most learners found it challenging to express grammatically correct sentences due to the significant differences in native language grammar and EFL students.

Consequently, they prefer to emphasize fluency rather than accuracy during speaking activities [4]. As stated by [4], students are not confident when delivering some sentences, mainly if they do public speaking, not just lack self-confidence. Still, students would get anxious because they are not proficient at expressing correct grammatically in speaking English. Furthermore, the teacher should have a solution to resolve the problem that teachers use hypnoteaching as a method in the learning process. In this study, the researcher had some step plan problem solving includes the formula or research questions.

To analyze the problem explained by a researcher on the study's background, the researcher formulated the following research question: How do teachers explore student's speaking skills used Hypnoteaching? and the objective of the study of this research as follows: "To describe how teachers explore student's speaking skills using Hypnoteaching". In this study, the researcher expected the findings or the result of this research expected to contribute to teachers and students, especially concerning hypnoteaching and speaking skills, and this research gave useful information about how to benefit the use of hypnoteaching as a method or strategy toward the Teaching and English learning process. However, this theory and this method hopefully can help the teacher to make easily manage the classroom.

\section{METHODOLOGY}

In this study, the researcher used a case study as the research design because it was suitable for the problem and helped the researcher conduct this study. Furthermore, this problem was done in M.A. Sabillarasyad by the three teachers. Therefore, it is suitable for theory. [5] said a case study helps the researcher explain how or why the case happened. In order to conduct this study researcher did some steps or activities to collect the data: The researcher takes an in-depth interview to teacher explore students' speaking skill using hypnoteaching, and the researcher formulates some steps in this instrument as follows: 
a) The researcher started the interview using open-ended questions based on the listing interview online.

b) Researcher interview one by one subjects with the questions

c) Researchers did audio recordings during an interview session with subjects.

d) The researcher transcribed file audio recording after the interview session.

On the other hand, the researcher analyzed the result data from data collection before the researcher interviewed the teachers with a theory analysis from [6].

\section{FINDINGS}

The researcher found that all the students relax or enjoy the learning process and fully understand and acknowledge the teacher's material from the research results. Furthermore, the students are able to memorize the material that was teachers delivered in the learning process. Therefore, students are more confident, and they feel closer to the teacher after the implementation of hypnoteaching. However, in this study, the researcher wants to describe how the teacher explores students speaking skill use hypnoteaching which consisted in three terms, teaching before used hypnoteaching as T1, and teaching process used hypnoteaching as T2 and teaching after used hypnoteaching T3

\subsection{The result of interviewed}

\subsubsection{Teaching before Used Hypnoteaching (T1)}

In this stage or condition, the teachers were challenging to manage the class, and while the teacher conveyed the material, the condition of students did not focus that affect to students could not understanding the material.

\subsubsection{Teaching Processed Used Hypnoteaching (T2)}

In this process, the teacher did process teaching in the learning process with hypnoteaching, the hypnoteaching was a teaching method used affirmative words, and the teacher gave positive words by repetition. The teacher leads them to pray first and give positive words to the class over. Furthermore, some teachers did elements hypnoteaching that the teacher gave the Hypno story. Another teacher used covert hypnosis to improve the students' focus in the learning process that means the teacher gave the material in another way such as a game, reading story, etc.

\subsubsection{Teaching after Used Hypnoteaching (T3)}

In this stage or condition, the teachers and students more closely and the student can reduce problem speaking skills because they learned by the hypnoteaching method. However, the students are able to memorize what the teacher delivers or said in the classroom because 
the teacher does hypnoteaching, which means the teacher gave affirmative words or positive words by repetition. Furthermore, the students could become more confident after the teacher applied hypnoteaching because the teacher with positive words stimulated the student, motivating them to resolve their speaking problem. Another result is that the students can manage their stress in the learning process and develop their ability, especially in speaking.

\section{DISCUSSION}

Some previous studies confirmed the result of this study that before has the same result with this study. However, in this study, different results from previous studies showed that the teacher used covert hypnosis to increase students' focus in the game's learning process. Furthermore, this study had a different result from the previous study that the teacher and students could closer; this study also used Hypno story, covert hypnosis, which one of the elements of Hypnoteaching. Furthermore, the teachers more accessible to managed their classrooms after they used Hypnoteaching and have a lot of advantages.

\section{CONCLUSION}

Students' speaking problems were reduced, and the students were more confident after the teacher used hypnoteaching, in which the teachers gave positive words to students by repetition. Furthermore, the students more relax and enjoy the learning process. Furthermore, the researcher found the HT1 as the teacher one used hypnoteaching in order for students to focus on their not being aware when the teacher did hypnoteaching that made teachers used covert hypnosis. Therefore the students feel more closely with the teacher when their inside or outside the class. The researcher concludes that Hypnoteaching was a suitable method for reducing students' speaking problems and helped the teacher manage the classroom in the learning process.

\section{REFERENCES}

[1] M. Heap, "Hypnosis," in Cambridge Handbook of Psychology, Health and Medicine, Second Edition, 2nd ed., New York, 2014, pp. 359-362.

[2] J. Wehbe and Y. Safar, "Hypnosis and Physiotherapy," Res. Gate, vol. 15, no. 168, 2015.

[3] A. W. Gunawan, Manage Your Mind for Succes. Gramedia Pustaka Utama, 2006.

[4]

K. Manurung, "Improving the Speaking Skill using Reading Contextual Internet-Based Instructional Materials in an EFL Class in Indonesia," Procedia - Soc. Behav. Sci., vol. 176, pp. 44-51, 2015. 
[5] R. Taylor and A. Thomas-Gregory, "Case Study Research," Nurs. Stand. (Royal Coll. Nurs. (Great Britain 1987), 2015.

[6] J. W. Creswell, Qualitative Inquiry and Research Design Choosing among Five Approaches, 3rd ed. London: SAGE Publication Ltd, 2013. 